\title{
Effects of Temperature, Light Intensity and Nitrogen Applica- tion on the Recovery of Photosynthesis in the Senescent Primary Leaves by the Removal of Foliage Leaves in Snap Bean
}

\author{
Shigetoshi SuzUKI and the late Taikichi TAKANO \\ College of Agriculture, Meijo University, Shiogamaguchi 1-501, Tempaku-ku, Nagoya 468-8502, Japan
}

(Received September 22, 2003)

\begin{abstract}
The effects of three environmental factors on the recovery of net photosynthetic rate $(\mathrm{Pn})$ in the senescent primary leaves by the removal of foliage leaves in snap bean plants (Phaseolus vulgaris L.) were examined. Effects of temperature were examined under three different conditions : $23 / 18,25 / 20$, and $28 / 23^{\circ} \mathrm{C}$ (day/night). Under these conditions, Pn at $25^{\circ} \mathrm{C}$ were not affected. Effects of light intensity were examined by covering the primary leaves with 1-3 layers of black cheesecloth. The recovery of Pn on a fresh weight basis decreased with increasing shade level. However, any difference was not observed in Pn on a dry weight basis. Since shading with black cheesecloth increased leaf extension and decreased leaf thickness, the effect of light intensity appeared to be through the effect on leaf morphology. Effects of nitrogen were examined by applying three different levels of nitrogen during the different experimental period. It became evident that the nitrogen level in the nutrient solution applied to plants is an important environmental factor affecting the recovery of $\mathrm{Pn}$.
\end{abstract}

Keywords: defoliation, environmental factors, photosynthesis, snap bean

\section{INTRODUCTION}

Net photosynthetic rates $(\mathrm{Pn})$ of the primary leaves are enhanced by defoliation of foliage leaves in snap bean plants (Suzuki and Takano, 2002), which suggest that a partially defoliated plant would adjust its photosynthetic ability to its own sink demand for photosynthates. This type of adjustment can be widely observed in plants growing in crop fields because of the feeding damage by insects (Turnipseed, 1972; Poston et al., 1976), the mechanical damage by an excess of climatic factors such as strong wind or hail storm (Weber and Caldwell, 1966), and artificial defoliation (Marek and Stewart, 1992 ; Suzuki and Takano, 2002). Just after the defoliation, photosynthesis is reported to be enhanced through an increase in stomatal conductance in soybean plants (Marek and Stewart, 1992). Thereafter, however, photosynthetic adjustment to a new level of the demand has been considered to be established in a wide range of plant species through a variety of mechanisms, including regulation of stomatal aperture and/or non-stomatal processes such as starch accumulation in chloroplasts, limitation for Pi availability in the cytosol, and end-product limitation in sucrose metabolism (Neals and Incoll, 1968 ; Gifford and Evans, 1981 ; Stitt, 1990). We proposed from the measurement of transpiration, $\mathrm{CO}_{2}$, and $\mathrm{O}_{2}$ exchange that the photosynthetic adjustment during 4-5 days after

Corresponding author: Shigetoshi Suzuki, fax : +81-52-835-7450,

e-mail : shiget @ccmfs.meijo-u.ac.jp 
defoliation in snap bean plants is mediated by non-stomatal mechanisms (Suzuki and Takano, 1992). Among them, sugar-mediated regulation of photosynthetic gene expression, in which hexokinase is likely to be one of the sensors in the signal transduction, is considered to play a pivotal role in the photosynthetic adjustment (Sheen, 1990; Jang and Sheen, 1994; Cheng et al., 1998 ; Pego et al., 2000 ; Smeekens, 2000). Studying the mechanisms of the photosynthetic adjustment at a molecular level is crucial for our further understanding of photosynthesis. Meanwhile in production of horticultural crops, sink-source balance within a whole plant is often altered to improve crop yield and quality by cultural management practices such as pinching, flower or fruit thinning, disbudding, or defoliation. Because photosynthesis is a process strongly affected by a variety of environmental factors, studying the influence of major environmental factors on the photosynthetic adjustment induced by those practices is also considered to be valuable for maintaining higher crop productivity.

In this paper, the effects of temperature, light intensity, and nitrogen application on the photosynthetic adjustment in the primary leaves induced by defoliation of foliage leaves in snap bean plants were examined to obtain a management guide in controlling these environmental conditions under which defoliation is conducted.

\section{MATERIALS AND METHODS}

Plant materials and defoliation. Bean seeds (Phaseolus vulgaris L. cv. Yamashiro Kuro Sando) were selected for uniformity and four seeds were sown in a black polyvinyl pot $(9 \mathrm{~cm}$ in diameter and $300 \mathrm{~cm}^{3}$ in volume) containing a mixture of equal volume of Kanuma pumiceous clay aggregates and vermiculite. After the primary leaves were fully expanded, two seedlings were selected for photosynthetic measurements by thinning. Unless otherwise stated, plants were grown in a phytotron (S-206W, Koito Industries, Ltd., Japan) under natural light conditions and a day $(0600-1800 \mathrm{HR}) /$ night $(1800-0600 \mathrm{HR})$ temperature regime of $25 / 20^{\circ} \mathrm{C}$, irrigated every day with a diluted commercial nutrient solution (Hyponex, Hyponex Corporation, U.S.A.) until excess solution drained from the bottom of the pots. Leaflets of trifoliate leaves were removed at the stage of full expansion of the second trifoliate leaf on about 20th day after seeding, thereafter the defoliation was repeated when new trifoliate leaves unfolded. Water loss from cut surface was prevented by covering with Vaseline.

Gas exchange measurements. Changes in Pn of the primary leaves were measured by an infra-red $\mathrm{CO}_{2}$ analyzer (ZAP, Fuji Electric Co., Ltd., Japan) in an open system as previously described (Suzuki et al., 1987). The rate of air flow in an assimilation chamber was $5 \mathrm{~L} / \mathrm{min}$. Temperature and relative humidity were maintained at $25^{\circ} \mathrm{C}$ and approximately $60 \%$, respectively. The photosynthetic photon flux density on the leaf surface was ca. $600 \mu \mathrm{mol} \mathrm{m}^{-2} \mathrm{~s}^{-1}$. Changes in Pn during the experimental period were shown as a scattered plots connected by arbitrary lines.

Effects of temperature conditions. After the beginning of defoliation, plants grown under a day/night temperature regime of $25 / 20^{\circ} \mathrm{C}$ were divided into three groups and each group of plants was transferred to one of the three different temperature conditions (S-206W, Koito Industries, Ltd., Japan) : $23 / 18,25 / 20$, and $28 / 23^{\circ} \mathrm{C}$ (day/night). Changes in net photosynthetic rates of the primary leaves at $25^{\circ} \mathrm{C}$ were measured.

Effects of shading. After the beginning of defoliation, the primary leaves were covered with 1-3 layers of black cheesecloth. Percentages of light interception by one, two and three layers of cheesecloth were $42.9,66.7$, and $79.3 \%$, respectively. Changes in net photosynthetic rates of the primary leaves were measured at $25^{\circ} \mathrm{C}$ under the photosynthetic photon flux density on the leaf of ca. $600 \mu \mathrm{mol} \mathrm{m}{ }^{-2} \mathrm{~s}^{-1}$.

Effects of nitrogen fertilizer levels. During the period before or after defoliation, plants 
Table 1 Ionic composition of nutrient solutions used in the experiment of the nitrogen effect.

\begin{tabular}{lccc}
\hline & \multicolumn{3}{c}{ Nitrogen levels } \\
\cline { 2 - 4 } & $\mathrm{N}=11 \mathrm{High} / \mathrm{me}$ & $\begin{array}{c}\text { Medium } \\
\mathrm{N}=6 \mathrm{me} / \mathrm{L}\end{array}$ & $\mathrm{N}=2 \mathrm{me} / \mathrm{L}$ \\
\hline $\mathrm{NO}_{3}{ }^{-}$ & 9 & 6 & 2 \\
$\mathrm{H}_{2} \mathrm{PO}_{4}^{-}$ & 3 & 3 & 3 \\
$\mathrm{SO}_{4}{ }^{2-}$ & 4 & 4 & 4 \\
$\mathrm{Cl}^{-}$ & - & - & 4 \\
$\mathrm{~K}^{+}$ & & 5 & \\
$\mathrm{Ca}^{2+}$ & 5 & 3 & 5 \\
$\mathrm{Mg}^{2+}$ & 3 & 3 & 3 \\
$\mathrm{Na}^{+}$ & 3 & - & - \\
$\mathrm{NH}_{4}{ }^{+}$ & 1 & - & - \\
\hline
\end{tabular}

were applied with nutrient solutions containing different levels of nitrogen (Table 1). In the experiment in which plants were applied with different levels of nitrogen before defoliation, plants were irrigated every day with tap water after defoliation. In the experiment in which plants were applied with different levels of nitrogen after defoliation, plants were irrigated with tap water or the nutrient solution containing a medium level of nitrogen for 11 days before defoliation.

\section{RESULTS}

The effects of temperatures on the rapid increase in Pn of the primary leaves expressed on a leaf area basis are shown in Fig. 1. In control plants, grown under the medium temperature condition, Pn decreased with aging. After defoliation, Pn of the primary leaves increased similarly under three different temperature conditions. Similar results were obtained in Pn on

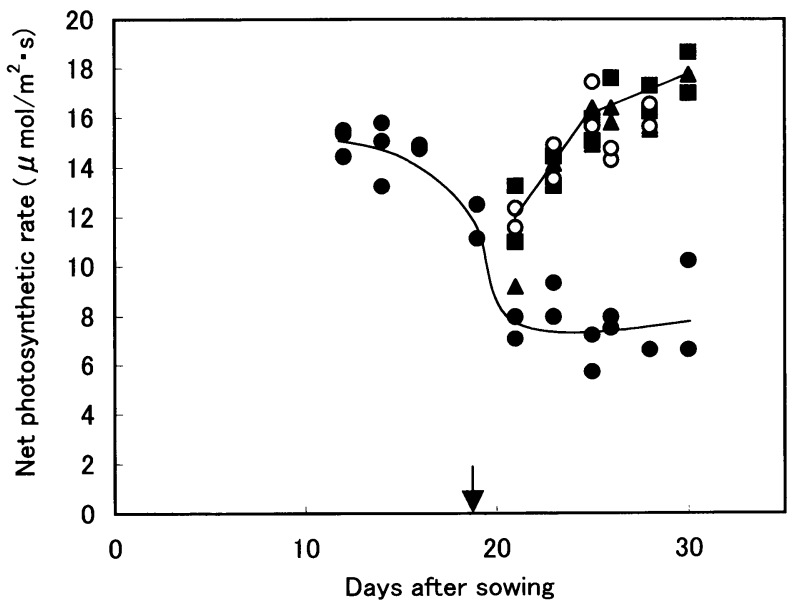

Fig. 1 The effects of temperatures and defoliation on net photosynthetic rates of the primary leaves. Defoliation of fully expanded leaflets of trifoliate leaves started on 19th day after sowing. Plants were grown at $25 / 20{ }^{\circ} \mathrm{C}$ (day/night) for 19 days after sowing, thereafter grown at three different

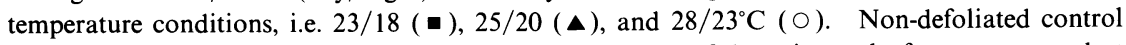
plants were grown at $25 / 20^{\circ} \mathrm{C}(\bullet)$. Photosynthetic rates of the primary leaf were measured at $25^{\circ} \mathrm{C}$. An arrow indicates the day when defoliation started. 
a leaf weight basis (data not shown).

Effects of shading on the rapid increase in Pn on a leaf area basis are shown in Fig. 2. With decreasing light intensity on the surface of the primary leaves covered with 1-3 layers of black cheesecloth, the enhancement in Pn after defoliation was diminished. In the plants shaded with one layer of black cheesecloth, the enhancement in Pn became slightly smaller than the unshaded plants. Furthermore, in the plants shaded with 2 or 3 layers of black cheesecloth, the rapid increase in Pn during 5 days after defoliation was not observed: duration of rapid increase in Pn was shortened and the enhancement in Pn was diminished. After 5 days of rapid increase, Pn increased at slower rates both in unshaded and shaded plants with one layer of cheesecloth, whereas Pn declined in the plants shaded with 2-3 layers of

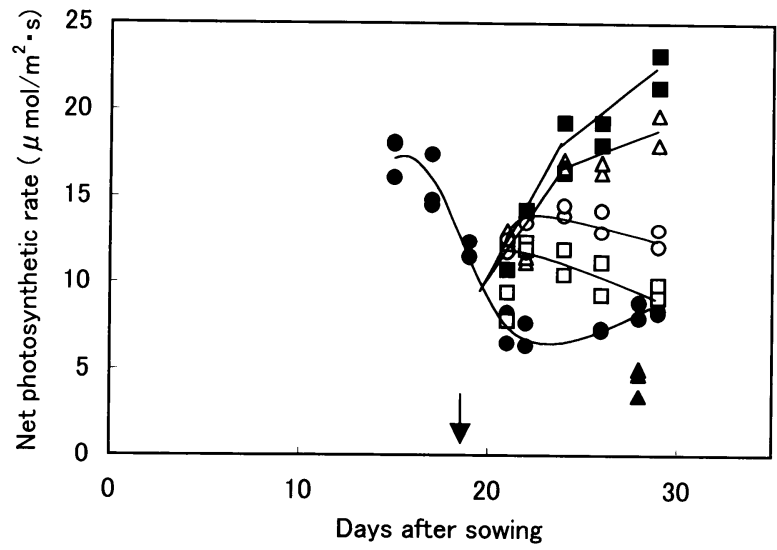

Fig. 2 The effects of shading and defoliation on net photosynthetic rates of the primary leaves expressed on a leaf area basis. Defoliation of fully expanded leaflets of trifoliate leaves started on 19th day after sowing, following which the primary leaves were covered with $0(\square), 1(\triangle), 2(O), 3(\square)$ layers of black cheesecloth. Net photosynthetic rates of the defoliated and non-defoliated control plants $(\bullet)$ were measured under the condition of PPF of ca. $600 \mu \mathrm{mol} \mathrm{m} \mathrm{m}^{-2} \mathrm{~h}^{-1}$. Closed triangles indicate net photosynthetic rates of the primary leaves of non-defoliated control plants covered with 2 layers of black cheesecloth. An arrow indicates the day when defoliation started.

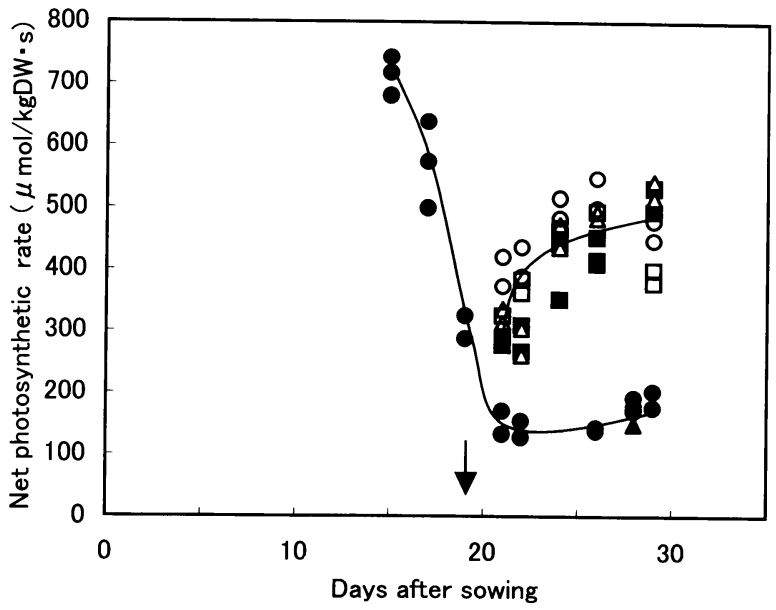

Fig. 3 The effects of shading and defoliation on net photosynthetic rates of the primary leaves expressed on a leaf dry weight basis. See Fig. 2 for symbols of the treatment and outlines of the experimental procedures. An arrow indicates the day when defoliation started. 
cheesecloth. Pn of non-defoliated plants covered with 2 layers of black cheesecloth decreased to very low values on 28 th day after sowing. Similar results were obtained in the enhancement of Pn on a fresh weight basis (data not shown). When Pn was expressed on a leaf dry weight basis, however, the effect of shading with 1-3 layers of cheesecloth became unclear ; Pn increased rapidly for 5 days after defoliation and thereafter maintained at constant rates both in unshaded controls and shaded plants with 1-3 layers of cheesecloth (Fig. 3). Specific leaf weight, an index of leaf thickness expressed as leaf dry weight per leaf area, was affected by shading : leaf thickness decreased with increasing degree of shading (Fig. 4).

Effects of different nitrogen levels applied during the period before defoliation on the rapid increase in Pn are shown in Fig. 5. The enhancement in Pn by defoliation was affected by nitrogen levels, being higher in the plants applied with higher nitrogen levels. In non-

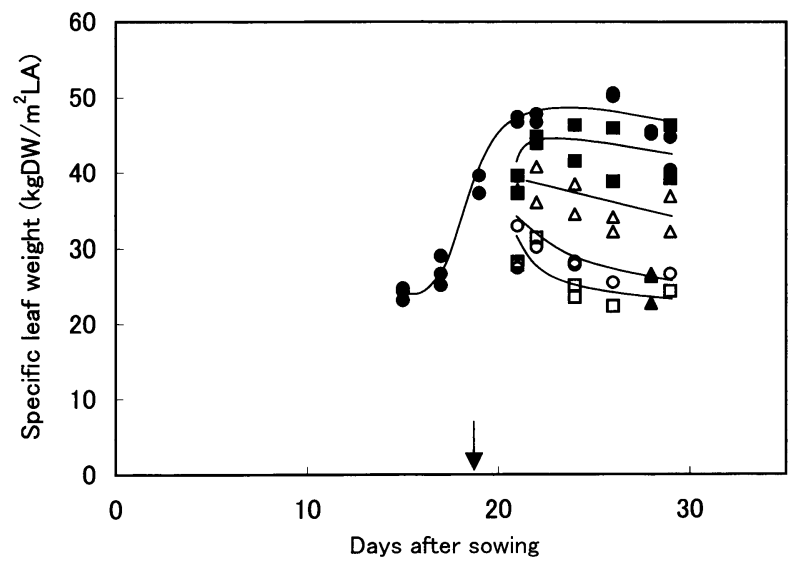

Fig. 4 The effects of shading and defoliation on the leaf thickness of the primary leaves. See Fig. 2 for symbols of the treatment and outlines of the experimental procedures. An arrow indicates the day when defoliation started.

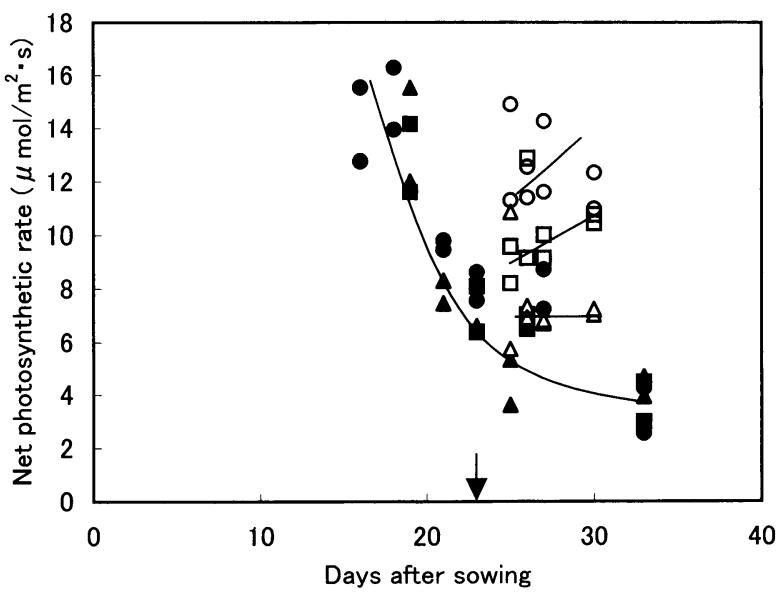

Fig. 5 The effects of nitrogen levels in nutrient solutions and defoliation on net photosynthetic rates of the primary leaves. Plants were irrigated every day with the nutrient solutions containing low $(\Delta, \Delta)$, medium $(\bullet, \square)$, and high $(\bullet, \bigcirc)$ levels of nitrogen for 23 days before defoliation, thereafter irrigated with tap water. Open and closed symbols indicate defoliated and nondefoliated plants, respectively. An arrow indicates the day when defoliation started. 
defoliated controls, however, Pn was not affected by nitrogen levels. Effects of nitrogen levels applied during the period after defoliation on the rapid increase in Pn are shown in Figs. 6 and 7. Nitrogen levels affected Pn of non-defoliated control plants as well as of defoliated plants. In plants applied with tap water during the period before defoliation and thereafter with nutrient solution containing different levels of nitrogen, Pn decreased rapidly to very low rates, thereafter enhanced rapidly both by defoliation and by application of nutrient solutions: Pn of defoliated plants applied with the high level of nitrogen increased up to fourfold. In plants applied with the nutrient solution containing the medium level of nitrogen before defoliation, Pn decreased at slower rates than those of plants applied with tap water, thereafter increased

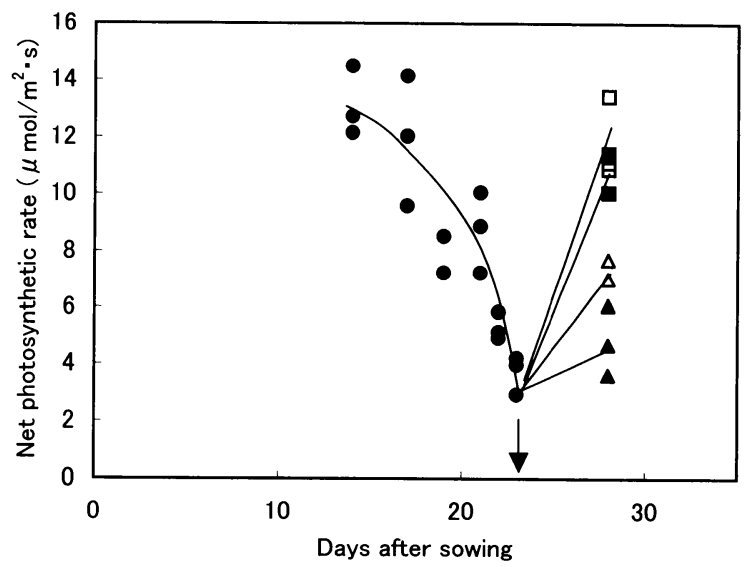

Fig. 6 The effects of nitrogen levels in nutrient solutions and defoliation on net photosynthetic rates of the primary leaves. Plants were irrigated with tap water $(\bullet)$ for 23 days before defoliation, thereafter with nutrient solutions containing low $(\Delta, \triangle)$ and high $(\bullet, \square)$ levels of nitrogen. Open and closed symbols indicate defoliated and non-defoliated plants, respectively. An arrow indicates the day when defoliation started.

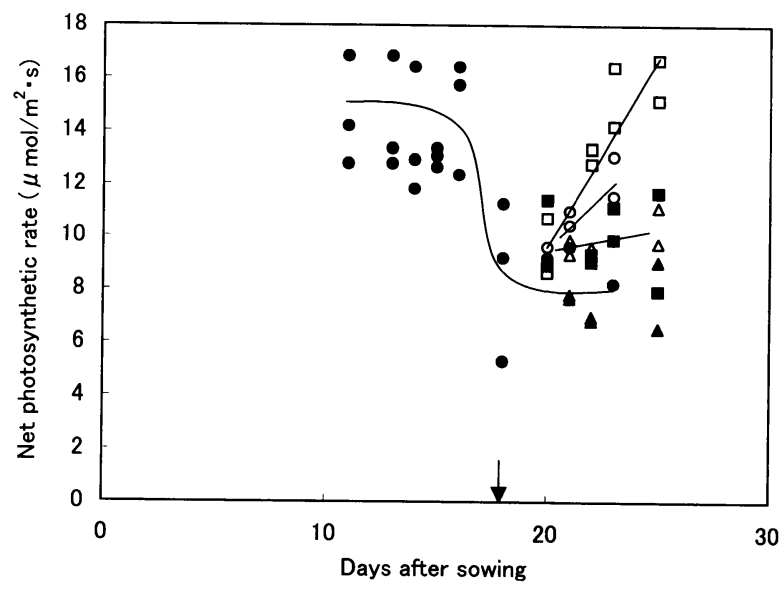

Fig. 7 The effects of nitrogen levels in nutrient solutions and defoliation on net photosynthetic rates of the primary leaves. Plants were irrigated with the nutrient solution containing a medium level of nitrogen $(\bullet)$ for 18 days before defoliation and thereafter with nutrient solutions containing low $(\Delta, \triangle)$, medium $(\bullet, \bigcirc)$, and high $(\bullet, \square)$ levels of nitrogen. Open and closed symbols indicate defoliated and non-defoliated plants, respectively. An arrow indicates the day when defoliation started. 
by defoliation: in defoliated plants, Pn were enhanced to the higher rates by the application of higher levels of nitrogen. Likewise, in non-defoliated control plants, Pn were enhanced by the application of the high level of nitrogen. However, in the non-defoliated plants applied with the low and medium level of nitrogen, Pn was not enhanced.

\section{DISCUSSION}

The effects of temperature were studied under a narrow range of temperature conditions, which is often encountered during the cultivation of snap bean plants, hence it is expected that the effects of these temperature conditions can be applied to a practical technique to regulate photosynthetic leaf function. Under the temperature conditions in this experiment, however, the effect of temperature on photosynthetic adjustment was not observed (Fig. 1), suggesting that this process is mediated by the mechanism which is not sensitive to a narrow range of temperature. A variety of mechanisms on the photosynthetic adjustment have been explained by chemical processes (Stitt, 1990), suggesting the involvement of temperature-dependent processes. Further studies are required to make clear the effect of temperature on the photosynthetic adjustment under a wider range of temperature conditions.

Photosynthetic adjustment expressed on a leaf area basis was affected by the degree of shading (Fig. 2), whereas it was not observed when expressed on a dry weight basis (Fig. 3). In the primary leaves shaded with cheesecloth, leaf extension growth was stimulated and leaf thickness decreased (Fig. 4). We reported that Pn of the unremoved leaves was adjusted to a newly formed requirement for photosynthates after partial defoliation through the morphological and/or physiological mechanisms, and morphological alteration in leaf area and thickness plays a central role at a lower degree of defoliation (Suzuki and Takano, 2002). Likewise, the degree of shading in the present experiment affected leaf morphology. Since any differences were not observed in photosynthetic adjustment expressed on a dry weight basis in the primary leaves covered with 1-3 layers of cheesecloth, it is not likely that photosynthetic adjustment is induced by a physiological mechanism. Practically, under dense vegetation, a lower light intensity and a smaller irradiated leaf area for photosynthesis by the light interception through the overlapping leaves may affect the ability of photosynthetic adjustment of the leaves.

Nitrogen levels applied to plants is one of the most important factors affecting the photosynthetic rates of the leaves; thus, photosynthetic ability of the primary leaves of snap bean plants were affected by nitrogen levels in a nutrient solution. Both in non-defoliated control and in defoliated plants, Pn was higher in the plants applied higher levels of nitrogen (Fig. 6, Fig. 7). However, when the plants were applied with nutrient solution during the period before defoliation and with tap water after defoliation, Pn was not affected by nitrogen levels in non-defoliated control plants (Fig. 5). In the plants applied with nitrogen after defoliation (Fig. 6), Pn was higher in the plants applied with higher levels of nitrogen both in non-defoliated control and defoliated plants, which would be deficient in nitrogen because they were grown with tap water during the period before defoliation (Fig. 6). These results suggest that, in the non-defoliated control plants, nitrogen absorbed during the period before defoliation would be translocated to younger developing organs without being utilized in the primary leaves during the period when plants were applied with tap water, whereas nitrogen absorbed after the period of nitrogen deficiency caused by application with tap water would be used to enhance Pn of the primary leaves. In defoliated plants, it is evident that nitrogen application, before or after defoliation, increased Pn of the primary leaves after defoliation. These results indicate that the effects of nitrogen on the enhancement of Pn were mediated through a nitrogen level-dependent mechanism both in defoliated and in non-defoliated 
control plants. Among a variety of photosynthetic enzymes, Rubisco is a key enzyme determining photosynthetic ability of the plants growing under the limited nitrogen supply because activity and protein level of this enzyme decrease in nitrogen-deficient plants (Sugiyama and Sakakibara, 2002). Meanwhile in the recovery process of photosynthesis in the soybean source leaf after leaf removal (Marek and Stewart, 1992) or leaf shading (Thorne and Koller, 1974), photosynthesis increased with increasing amount and activity of Rubisco. It has also been proposed that nitrogen- (Plumley and Schmidt, 1989; Sugiharto and Sugiyama, 1992) and sugar-mediated (Sheen, 1990 ; Jang and Sheen, 1994 ; Pego et al., 2000 ; Smeekens, 2000) regulation of photosynthetic gene expression including the Rubisco small subunit play important roles. Thus, it is likely that a mechanism by which amount and activity of photosynthetic protein are influenced would be involved in the photosynthetic adjustment in the primary leaves after defoliation of foliage leaves and therein nitrogen as well as sugars would play an important role as a signal for increasing gene expression and/or as a raw material for photosynthetic protein synthesis.

In conclusion, among the environmental factors studied in this experiment, nitrogen level in the nutrient solution is the most important factor affecting photosynthetic adjustment. Practically, this suggests the importance of nitrogen fertilization to enhance the ability of photosynthetic adjustment.

\section{REFERENCES}

Cheng, S.-H., Moore, B. D., Seemann, J. R. 1998. Effects of short- and long-term elevated $\mathrm{CO}_{2}$ on the expression of ribulose-1,5-bisphosphate carboxylase/oxygenase genes and carbohydrate accumulation in leaves of Arabidopsis thaliana. Plant Physiol. 116: 715-723.

Gifford, R. M., Evans, L. T. 1981. Photosynthesis, carbon partitioning, and the yield. Annu. Rev. Plant Physiol. 32 : 485-509.

Jang, J.-C., Sheen, J. 1994. Sugar sensing in higher plants. Plant Cell 6 : 1665-1679.

Marek, L. F., Stewart, C. R. 1992. Photosynthesis and photorespiration in presenescent, senescent, and rejuvenated soybean cotyledons. Plant Physiol. 98 : 694-699.

Neals, T. F., Incoll, L. D. 1968. The control of leaf photosynthesis rate by the level of assimilate concentration in the leaf: A review of the hypothesis. Bot. Rev. $34: 107-125$.

Pego, J. V., Kortstee, A. J., Huijser, C., Smeekens, S. C. M. 2000. Photosynthesis, sugars, and the regulation of gene expression. J. Exp. Bot. 51 : 407-416.

Plumley, F. J., Schmidt, G. W. 1989. Nitrogen-dependent regulation of photosynthetic gene expression. Proc. Natl. Acad. Sci. USA $86: 2678-2682$.

Poston, F. L., Pedigo, L. P., Pearce, R. B., Hamond, R. B. $1976 . \quad$ Effects of artificial and insect defoliation on soybean net photosynthesis. J. Econ. Entomol. 69 : 109-112.

Sheen, J. 1990. Metabolic repression of transcription in higher plants. Plant Cell 2: 1027-1038.

Smeekens, S. 2000. Sugar-induced signal transduction in plants. Annu. Rev. Plant Physiol. Plant Mol. Biol. 51 : 49-81.

Stitt, M. 1990. Fructose-2,6-bisphosphate as a regulatory metabolite in plants. Annu. Rev. Plant Physiol. Plant Mol. Biol. 41 : 153-185.

Sugiharto, B., Sugiyama, T. 1992. Effects of nitrate and ammonium on gene expression of phosphoenolpyruvate carboxylase and nitrogen metabolism in maize leaf tissue during recovery from nitrogen stress. Plant Physiol. 98 : 1403-1408.

Sugiyama, T., Sakakibara, H. 2002. Regulation of carbon and nitrogen assimilation through gene expression. In "Photosynthetic Nitrogen Assimilation and Associated Carbon and Respiratory Metabolism" (ed. by Foyer, C. H., Noctor, G.). Kluwer Academic Publishers, Dordrecht, p 227-238.

Suzuki, S., Yamada, K., Takano, T. 1987. Effect of succinic acid 2,2-dimethylhydrazide on drought tolerance of bean plant. Sci. Rept., Fac. Agr., Meijo Univ. 23 : 15-22.

Suzuki, S., Takano, T. 1992. Effect of trifoliate leaf-removal on changes in photosynthesis and stomatal 
resistance of the primary leaf of snap bean plants. J. Jpn. Soc. Hortic. Sci. 61 (Suppl. 2) : 30-31 (in Japanese).

Suzuki, S., Takano, T. 2002. Restoration of photosynthesis in the senescent primary leaves by the removal of foliage leaves in snap bean plants. Sci. Rept., Fac. Agr., Meijo Univ. 38 : 7-14.

Thorne, J. H., Koller, H. R. 1974. Influence of assimilate demand on photosynthesis, diffusive resistances, translocation, and carbohydrate levels of soybean leaves. Plant Physiol. 54 : 201-207.

Turnipseed, S. G. 1972. Response of soybean to foliage losses in South Carolina. J. Econ. Entomol. 65 : 224-229.

Weber, C. R., Caldwell, B. E. 1966. Effects of defoliation and stem bruising on soybeans. Crop Sci. 6 : 25-27.

\section{〈和文抄録〉}

\section{インゲンマメの老化初生葉における本葉切除による光合成の回復に及ぼす 温度, 光強度および窒素施用の影響}

\section{鈴木 茂 敏・故 高野泰吉}

\section{名城大学農学部}

インゲンマメ (Phaseolus vulgaris L.cv. Yamashiro Kuro Sando) の老化初生葉における本葉切 除による純光合成速度の回復に及ぼす 3 種の環境要因の影響を調べた. 温度の影響については, $23 / 18^{\circ} \mathrm{C}, 25 / 20^{\circ} \mathrm{C}, 28 / 23^{\circ} \mathrm{C}$ (昼温/夜温) の条件で調べたが, $25^{\circ} \mathrm{C}$ における純光合成速度の回復 に及ほす明確な影響は認められなかった。光強度の影響は, 初生葉を 1 亿枚の黒寒冷紗で覆うこ とにより調べた. 遮光の程度が高まるにつれて, 純光合成速度の回復は, 葉面積当たりで表現した 場合低下したが, 葉重当たりで表現した場合には遮光の影響は認められなかった。遮光により葉の 面積は拡大し厚さは減少したことから, 光強度の影響は葉の形態に及ほす影響が大きいことが考 えられた。窒素施用濃度の影響は, 異なる濃度の窒素を含む液肥を時期を変えて施用して調べた。 その結果, 窒素施用濃度は本葉切除後の初生葉の光合成回復に大きな影響を及ほす要因であるこ とが明らかになった。 